\title{
HAZARD OF SINKHOLE FLOODING TO A CAVE HOMININ SITE AND ITS CONTROL COUNTERMEASURES IN A TOWER KARST AREA, SOUTH CHINA
}

\section{Fang Guo}

Key Laboratory of Karst Dynamics, Institute of Karst Geology, Chinese Academy of Geological Sciences, No.50, Qixing road, Guilin, 541004, China; The International Research Center on Karst under the Auspices of UNESCO, Guilin, 541004,China,gfkarst@126.com

\section{Guanghui Jiang}

Key Laboratory of Karst Dynamics, Institute of Karst Geology, Chinese Academy of Geological Sciences, No.50, Qixing road, Guilin, 541004, China; The International Research Center on Karst under the Auspices of UNESCO, Guilin,541004,China,bmnxz@126.com

\section{Kwong Fai Andrew Lo}

College of Science, Chinese Culture University, Taiwan, 55, Hwa-kang Road, Taipei, 111, Taiwan, ufab0043@ms5.hinet.net

\section{Qingjia Tang}

Key Laboratory of Karst Dynamics, Institute of Karst Geology, Chinese Academy of Geological Sciences, No.50, Qixing road, Guilin, 541004, China; The International Research Center on Karst under the Auspices of UNESCO, Guilin, 541004,China, qjtang@karst.ac.cn

\section{Yongli Guo}

Key Laboratory of Karst Dynamics, Institute of Karst Geology, Chinese Academy of Geological Sciences, No.50, Qixing road, Guilin, 541004, China; The International Research Center on Karst under the Auspices of UNESCO, Guilin,541004,China,gylguo@karst.ac.cn

\section{Shaohua Liu}

Key Laboratory of Karst Dynamics, Institute of Karst Geology, Chinese Academy of Geological Sciences, No.50, Qixing road, Guilin, 541004, China; The International Research Center on Karst under the Auspices of UNESCO, Guilin, 541004, China, liushaohua@karst.ac.cn

\begin{abstract}
Zengpiyan Cave, one of the most important cave hominin sites of the Neolithic in the South of China, was listed on the national register of cultural preservation sites in 2001. Large quantities of precious material in the Zengpiyan site were unearthed since the beginning of the trial excavation in 1973. These materials include hominin skeletal remains, fire pits, human burials, stone implements, tools fashioned from mollusk shells and animal or plant fossils.
\end{abstract}

According to the historical record, ancient people lived in caves in the karst plain of Guilin. They moved out of the caves approximately 7,000 years ago. These cave hominin sites provide important material for understanding ancient environmental change and human prehistory. However, the exploratory shaft of Zengpiyan had no appropriate treatment after the initial excavation. Groundwater flooded the exploratory shaft due to frequent rises in the water table, resulting in collapse of the exploratory shaft shoring as well as some other serious damages. Even though some rescue and protection measures were taken, for example, slope supporting and backfill treatment, they failed to eliminate the hidden trouble caused by rapid fluctuation of groundwater levels during the rainy season. Rapid urbanization is also affecting this region. Infrastructure construction of the city changes the hydrogeological conditions of the karst, increasing the area of impervious surface and risks of urban flooding. Moreover, an increase of extreme climate events may lead to frequent flooding of the site by groundwater. Therefore, a focused hydrogeological investigation was carried out to study the status of the site and karst development, and 
the mechanism of groundwater movement at local and regional scales. These surveys include borehole drilling, electrical resistivity surveys, computed tomography (CT) scanning technology, dye tracer tests, groundwater monitoring, and hydrochemistry analysis. The results show that the site is located in the seasonal fluctuation zone of the groundwater. Water level in the karst aquifer is sensitive to rainfall. Continuous rainstorms lead to synchronous rising of the groundwater level in both the cave and the aquifer. In addition, surface runoff and urban sewers cannot discharge smoothly, resulting in surface water backflooding into the cave entrance. Therefore, controlling the recharge of groundwater and the influx of surface runoff, and dredging a groundwater discharge channel are all important in order to reduce the damage of flooding to the archaeological sites. Based on these detailed investigations and research results, countermeasures for flood control and archaeological site protection were put forward.

We recommend that the engineering measures should combine curtain grouting, drain construction, and effective water resources management for the entire basin. Even though the measures are feasible, we can't promise a perfect damage control of the ruins by water due to the complex hydrogeological conditions in the covered karst area.

\section{Introduction}

Guilin in Southern China not only has a unique karst Fengcong and Fenglin landscape in the world, but also a long cultural history. Evidences of human activities date back 10,000 years B.P. According to the investigation from the Chinese Cultural Relics Department, 71 caves in Guilin have evidence of ancient human activities. These sites provide abundant artifacts and human remains for archaeological excavation (Wei, 2011). However, karst development and recent human activities raise challenges for environmental protection of these cave archaeological sites. Karst develops well in Guilin due to geology and climate conditions. Relative groundwater dynamics and generated corrosion and dissolution processes are active, resulting in frequent karst collapse occurrences, and threatens the preservation of cave relics.

The Guilin basin is a covered karst region. The interface between the surface soil and the sub-strata is located within the seasonal fluctuation (vadose) zone of the groundwater aquifer. Fluctuations in the groundwater elevation and its erosive capacity can not only cause numerous caverns within the bedrock, but can also carry off soil particles by erosion, the main driving force of karst collapse. Some cave relic sites in Guilin are also located within the groundwater seasonal fluctuation zone. It is inevitable that they will be disturbed by this groundwater fluctuation, with high risk of geological hazards from erosion and collapse.

\section{Study Area}

The Zengpiyan Cave was one of the residences and cemeteries of ancient residents in the Guilin area from 12,000 to 7,000 years ago. The cave is located in an isolated carbonate hill in a tower karst plain in Southwest Guilin. The surface of this plain has an elevation of $154 \mathrm{~m}$ above sea level. This cave, developed in the sparite and calcirudite from the Rongxian Group of the Devonian system $\left(\mathrm{D}_{3} \mathrm{r}\right)$, is composed of a dry cave and a water cave (Figure 1). The dry cave is where the ancient humans lived and has a $10 \mathrm{~m}$ wide and $4 \mathrm{~m}$ high entrance (if not stated, 'cave' mentioned in this paper always indicates the dry cave). The entrance of the cave faces south, and the rest of the cave extends to northeast for $20 \mathrm{~m}$. The altitude of the cave bottom coincides with the outside ground. A three meters thick cultural layer is deposited in the dry cave, carrying rich information from 12,000 B.P to Song Dynasty (960-1279 A.D.). In 1973, fossil remains of pre-historic human, stone implements, bone tools and pottery pieces dating some ten thousand years B.P. were unearthed within the cave. The cave has since become recognized as one of the most important repositories of human relics from the Neolithic Age in South China. The elevation of the cave floor ranges from 154 to $154.8 \mathrm{~m}$. Archaeological excavations produced seven main vertical test pits, the deepest to a depth of $3 \mathrm{~m}$. Evidence of intense dissolution of the limestone bedrock could be found in the bottom of the pit.

Groundwater levels in this area fluctuate in the range of 149.59 to $154.93 \mathrm{~m}$ elevation. Therefore, the cave is located in the groundwater seasonal fluctuation zone. Immersion and flow of the groundwater causes a series of problems including cave sediment softening, erosion and removal, collapses of the test pits, bottom collapse, and cave pollution. Controlling the groundwater level and its rate of fluctuation as well as water pollution are important for the protection of the site. 


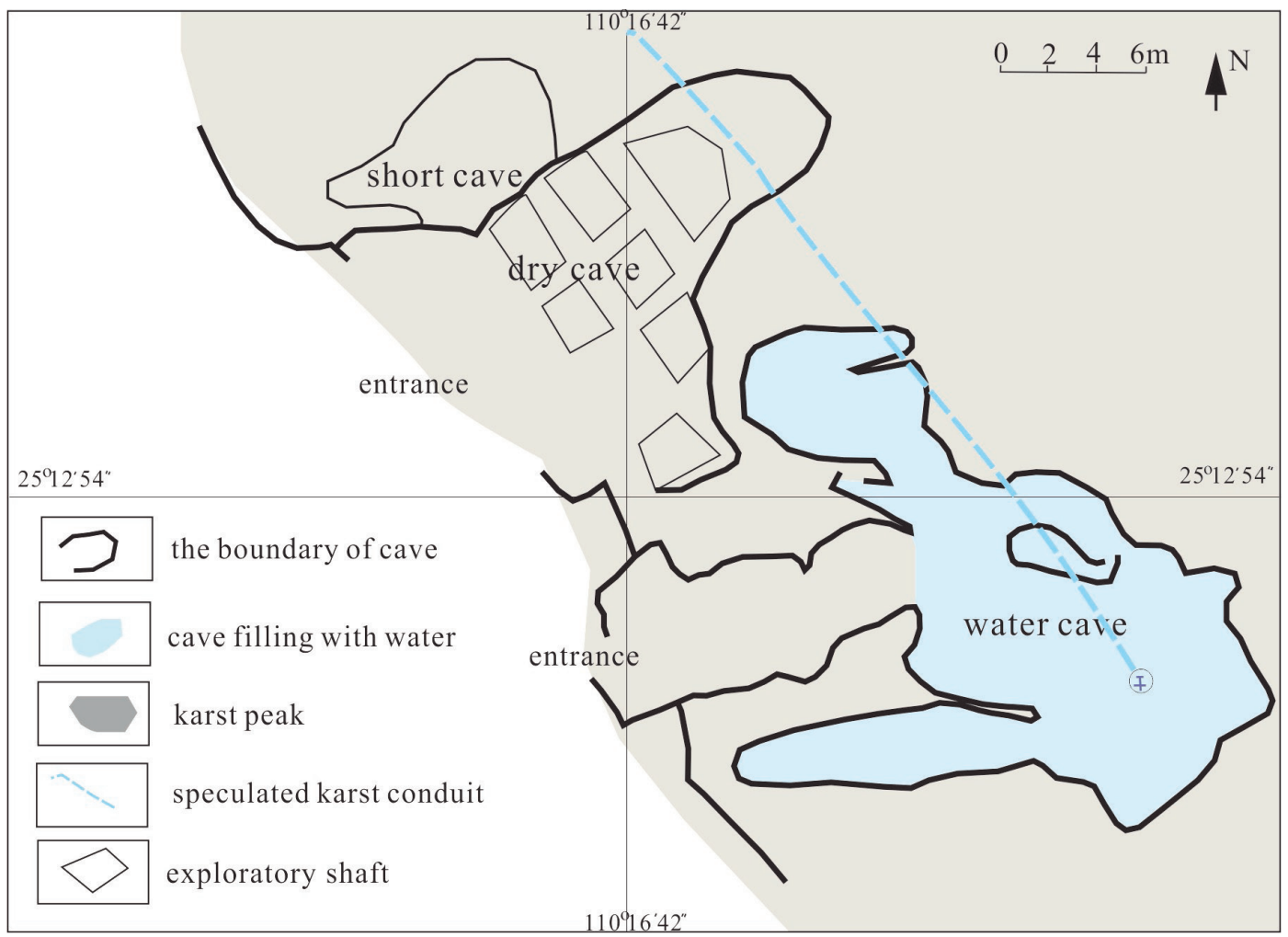

Figure 1. Schematics of the Zengpiyan Cave system. Modified from Qin et al. (2011).

The Guilin basin is a narrow syncline that trends in a south-north direction. The two sides, in the east and west, are high mountains, in which sandstone is distributed. The central part of the basin is developed in the Upper Devonian limestone. The pure limestone has a thickness of 300 to 400 $\mathrm{m}$, forming the stone peaks and underlying karst aquifer in the basin. The Lijiang River flows from the north of the basin, and flows out to the south, becoming a regional discharge base level for the basin (Figure 2). Surface water and groundwater recharges the Lijiang River from the east and the west. The Lijiang River originates from non-karst area in the upstream of Guilin City. Silt and gravel carried by surface water, and red clay from limestone weathering, form a residual cover over the limestone strata. The Groundwater source can be attributed to scattered rainfall recharge from the cover layer and lateral runoff from the adjacent hills. Groundwater distribution is heterogeneous, indicating cavernous porosity around the hill, making groundwater more plentiful in some places. The peak, under which the Zengpiyan site is located, has a projected area of $36,950 \mathrm{~m}^{2}$. Under the site there is a pool with an area of $301 \mathrm{~m}^{2}$, and it is likely connected to another pool to the northwest of the peak (Figure 1). These two pools in caves were used as water supply source, supplying $500 \mathrm{~m}^{3} / \mathrm{d}$ of water and never dried out.

\section{Study Methodology}

The hydrogeological investigation in this karst area aims to study the groundwater storage pattern and movement. It also characterizes the spatial variance of karst development, and connections between karst features and groundwater behavior, in order to provide the basis for engineering design and implementation to modify groundwater movement. Although direct groundwater encroachment is observed only at the cave archaeological site, it is influenced by groundwater movement over a much broader area. Therefore, determination of the range of groundwater flow paths is a crucial task. This study selects two scales of exploration scope, including regional scale and local scale. The regional scale study aims at understanding the formation condition and groundwater flow paths by geological analysis and hydrogeological investigation. The catchment area of hydrogeological unit and its boundaries are then determined. The local scale aims at studying the specific locations of karst conduit development and the source and direction of groundwater which has direct connection with Zengpiyan Cave. Historical and present groundwater exploitation and utilization data in this area were collected during the regional hydrogeological survey. The local scale groundwater investigation was 


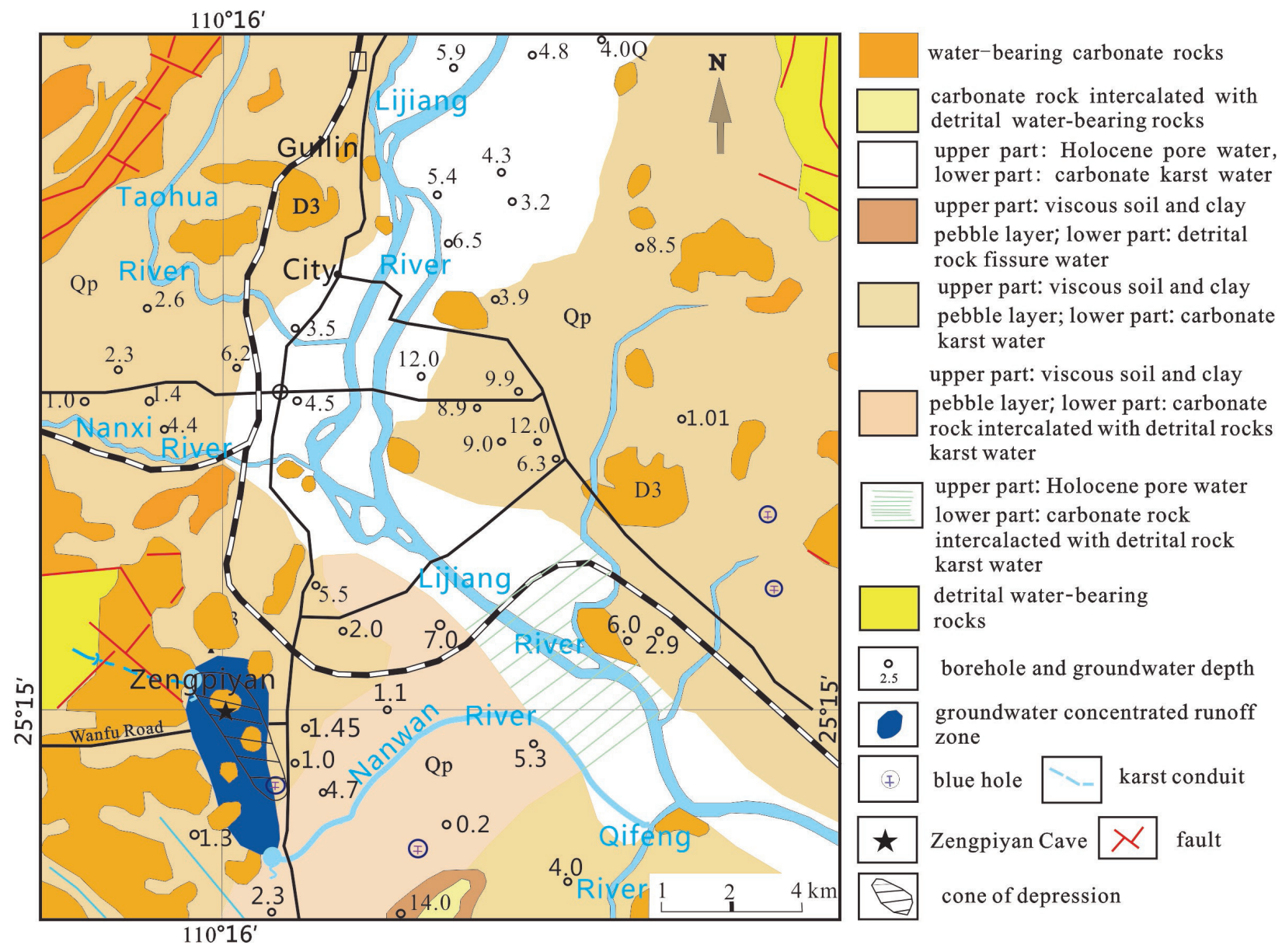

Figure 2. Regional hydrogeological map of Zengpiyan. Modified from Qin et al. (2011).

done through groundwater monitoring, hydrochemical analysis, water pumping tests, tracer tests, and geophysical survey methods.

\section{Results and Discussion Hydrogeological Investigation}

The hydrogeological unit where the Zengpiyan cave is located extends from clastic rock mountains in the northwest, flowing through the plain in the basin, and then ends up in the Lijiang River to the southeast of the cave. However, the lateral boundaries of the flow unit are not clear. There are two surface rivers outside Zengpiyan Cave in the north (Nanxi River) and in the south (Nanwan River), respectively (Figure 2), but they can't be the groundwater discharge boundary due to their insufficient incision into the aquifer. Within this unit, the mountainous area is much smaller than that of the plain. Most flooding generated from the mountains is discharged by streams and ditches, and at baseflow period, most of the mountain runoff is recharged to groundwater in the plain. Rainfall in the plain recharges the groundwater. With urbanization, surface runoff generated by imperious surface flows to stormwater drains. Waste water from the urban area is delivered to sewage treatment plants. Pools in the plain can retain some rainwater, but their total area is relative small in size. Most of the discharge in the Nanxi River is coming from domestic wastewater. The Nanwan River originates from a spring, but it is silted up seriously during its course, resulting in limited water discharge capacity. Therefore, most runoff is discharged to the Lijiang River from the aquifer. The riverbed of the Lijiang River has a thickness of $50 \mathrm{~m}$ and is composed of sand gravel. Springs exist in the riverbed but are buried by sand and gravel. The spring's outlets in the riverbed were discovered through interviews with local peoples. In the karst plain, natural groundwater outlets are located in the caves within the peaks, such as Zengpiyan. The depth of hand dug wells in the rural areas is usually less than $10 \mathrm{~m}$, but they can still satisfy household water demand. 
Zengpiyan Cave is located in a karst tower, close to the upstream part of the hydrogeological unit. No surface stream exits in the neighborhood, and caves are the important water storage systems. Groundwater level fluctuates frequently, reflecting good recharge and discharge conditions. Because the groundwater depth ranges from 2-4 $\mathrm{m}$ (basically lies in the vicinity of the interface between the covering layer and the karst aquifer), pools in the covering layer has close relationship with groundwater. The pool in the Zengpiyan Cave and the surrounding aquifer has good relationship with other pools in the hydrogeological unit. A dye tracer test shows that groundwater flows from the north and west of Zengpiyan to the water cave (Figure 1). The water then flows to pools to the south. Borehole drilling and CT scanning indicates that karst features are more developed near the cave entrances than in other parts of the karst terrain. Hydrochemical analysis suggests that an abnormal zone which has significantly different water chemistry is found in the cave entrance and in the more intensive developed karst zones.

Hydrogeological investigations indicate that Zengpiyan Cave and its surrounding area belong to a concentrated flow zone in the aquifer of the Guilin Basin, and their groundwater storage is considered to be the largest in the basin.

\section{Groundwater Concentrated Flow Zone}

Delineation of a groundwater concentrated flow zone was the most significant finding of this hydrogeological investigation. Determination of this zone was achieved by using data from hydrogeological analysis and pumping tests. A pumping test was done in a blue hole to the southeast of Zengpiyan Cave in 1960. At the same time as the test, groundwater levels in the Zengpiyan boreholes and blue holes to the northwest of the cave were observed. According to the contours of the water table drawn down during the pumping test, an elliptical cone of depression trending in a SW direction along its long axis was produced. The radius of influence in the SW direction is much bigger than the other directions, indicating that water transmissibility from the SW direction is greater, forming a groundwater concentrated flow zone in the aquifer (Figure 2). The Zengpiyan site is located in this groundwater concentrated flow zone.

Groundwater is solutionally aggressive in the concentrated flow zone, and karstification, including cave development is intense in the aquifer there. For example, a cave is developed in the peak, which is $400 \mathrm{~m}$ away from Zengpiyan to the north. In the rainy season, the lowest parts of the caves regularly collect water, suggesting these caves are most likely located in the groundwater level fluctuation zone. A $6 \mathrm{~m}$ high cave was found in the borehole in the north of Zengpiyan, and according to CT electromagnetic wave, the cave is $28 \mathrm{~m}$ wide. For 21 boreholes drilled around Zengpiyan Cave, 10 boreholes contained caves, with the highest being $10 \mathrm{~m}$ high.

Groundwater discharged from springs also reaches the concentrated flow zone. In some places, groundwater rises to the top surface after rainstorm, indicating that the groundwater recharge comes from higher elevations, and then flows into the plain after moving long distance. Strong groundwater activities often result in frequent karst collapse.

Within the groundwater concentrated flow zone, boreholes have large pump test flows, suggesting that the aquifer has high water storage there. Groundwater exploitation in the Guilin Basin usually uses well drilling and water pumping from caves. For example, cavern water like that at the Zengpiyan Cave is common in the Guilin Basin, and commonly used for drinking.

Water discharge can be divided into three levels of productivity according to the specific capacity for boreholes by pumping tests When specific capacity is lower than $1 \mathrm{~L} /(\mathrm{s} \bullet \mathrm{m})$ (the unit means the water inflow when water table decreases by one meter), it means the water yield of borehole is small. This often happens when borehole is located in a part of the aquifer where karst is undeveloped, indicating that karst media is primary in fissure and fracture. When the borehole flow ranges from $1-10 \mathrm{~L} /(\mathrm{s} \bullet \mathrm{m})$, the flow belongs to medium level, indicating that there are some dissolution fractures existing in the aquifer where borehole is located. Water yield is abundant in the aquifer when the specific capacity is bigger than $10 \mathrm{~L} /(\mathrm{s} \bullet \mathrm{m})$, suggesting that karst is well developed in the aquifer.

Flow of water pumping from caves is greater than from boreholes. For example, pumping test in the boreholes around Zengpiyan Cave showed that the scope of groundwater depth declining is less than $1 \mathrm{~m}$ when the pumping load is $2.8 \mathrm{~L} / \mathrm{s}$. When the pumping load reaches $10 \mathrm{~L} / \mathrm{s}$, groundwater declining is still less than one meter within an hour. The coefficient of aquifer transmissibility 
in the concentrated flow zone was 9-26 m/s according to pumping test, and the groundwater flow velocity was $10-40 \mathrm{~m} / \mathrm{d}$ as calculated by tracer tests.

\section{Treatment Scheme of Water Damage}

The results of a hydrogeological survey provide the basis for mitigation of water damage in Zengpiyan Cave. The treatment concept is to reduce the risk of groundwater flooding, erosion, and pollution of the site through engineering measures. The objectives are to control the groundwater level to a threshold value and to control its fluctuation velocity within a permissible range.

Prior to engineering measures to control groundwater movement, karst water types should be determined first. Karst water types are classified as subterranean stream (water-bearing conduits), concentrated flow zone, and general karst fissure water (Table 1). The subterranean stream has the strongest hydrological dynamics, and thus it has the lowest engineering success rate. If the subterranean stream is blocked, there is a risk of water leakage and collapse. Besides, the upstream of underground stream often becomes flooded after the stream is blocked. For groundwater concentrated flow zone, karst collapse is highly probable. Another characteristic is that groundwater is usually abundant in this zone, with good interconnection of karst media, resulting in high water transmission. Curtain grouting in part can reduce water inflow, but the accompanying environmental change should be considered and evaluated. By contrast, engineering treatment in karst fissure areas, in general, is relatively simple.

Eight treatment measures for relieving groundwater hazard are proposed, including monitoring, evaporation, dewatering, pumping, impermeable layer setting, curtain grouting, and environmental treatment. These

Table 1. Karst water types and corresponding treatment scheme.

\begin{tabular}{|l|l|l|l|l|}
\hline $\begin{array}{l}\text { Karst water } \\
\text { types }\end{array}$ & $\begin{array}{l}\text { Specific } \\
\text { capacity/ } \\
(\mathrm{L} / \mathrm{s} \cdot \mathrm{m})\end{array}$ & $\begin{array}{l}\text { Karst } \\
\text { developed }\end{array}$ & $\begin{array}{l}\text { Engineering technical } \\
\text { measures }\end{array}$ & $\begin{array}{l}\text { Geological } \\
\text { hazard }\end{array}$ \\
\hline $\begin{array}{l}\text { Subterranean } \\
\text { stream }\end{array}$ & $>10$ & $\begin{array}{l}\text { very } \\
\text { heterogeneous }\end{array}$ & $\begin{array}{l}\text { blocking, water } \\
\text { diversion by tunnel }\end{array}$ & $\begin{array}{l}\text { flooding, } \\
\text { dam falling }\end{array}$ \\
\hline $\begin{array}{l}\text { Concentrated } \\
\text { flow zone }\end{array}$ & $>10$ & $\begin{array}{l}\text { relatively } \\
\text { heterogeneous }\end{array}$ & $\begin{array}{l}\text { Curtain grouting, pump } \\
\text { and drain of water, or } \\
\text { water diversion by open } \\
\text { channel }\end{array}$ & collapse \\
\hline $\begin{array}{l}\text { General karst } \\
\text { fissure }\end{array}$ & $<10$ & even & pumping & none \\
\hline
\end{tabular}

eight measures should be conducted coordinately, and prioritized according to minimize damage to the environment. A small scale experiment should be performed first, to confirm its effectiveness before further investment scale starts.

\section{Environmental Monitoring}

The aims of monitoring are to learn groundwater hydrological dynamics and hydrochemistry at all times, to observe possible immersion, scour, and pollution events; to understand the impact of surrounding human activities on the cave relics and environment; and to prevent new problems from occurring. Monitoring includes: atmospheric environment change (namely, air temperature, precipitation, humidity, wind speed, pressure, and $\mathrm{CO}_{2}$ content); and, groundwater environment (namely, water level, flow, fluctuation velocity, water temperature, and water quality) in both cave drip water and in groundwater.

\section{Water Draining by Evaporation}

Enhance the water draining rate of groundwater by means of increasing evaporation. Because groundwater depth in and surrounding Zengpiyan Cave ranges from 2-4 $\mathrm{m}$, tree roots can use groundwater directly. Using trees to enhance groundwater discharge is a measure of not only environmental friendly, but also economical. Specifically, increase the green area in and surrounding Zengpiyan Cave, using tree species which have high water consumption during plant growth period.

\section{Water Draining by Open Channel}

The aim of water draining by open channel is to discharge surface runoff and part of groundwater during raining periods, in order to reduce the groundwater level, and to solve the problem of groundwater level exceeding the warning level. According to interviews with local people, surface runoff is discharged inefficiently during rainstorms. So much so that surface runoff can flow back into the caves, which is a key factor of rising groundwater level during rainstorms. The main reason for inefficient surface runoff is that there are still some areas without rainwater conduit in the upstream parts of the Zengpiyan Cave hydrogeologic unit. Surface runoff flows to the low-lying areas, and then recharges groundwater. Under extreme conditions, rainwater conduits nearby can't 
drain fast enough, and then rainwater flows backward to Zengpiyan Caves following the karst conduits. To improve the capacity of rainwater draining, building and improvement of open channels and conduits is proposed (Mo and Zhang, 2011).

\section{Water Pumping}

Water pumping means when groundwater table exceeds the warning level, groundwater should be pumped directly from the caves, in order to protect cave relics. Or before the rainstorm comes, groundwater in caves can be pumped out to make room for rainwater. It has been proven feasible to lower the groundwater table by water pumping through pumping test performed and reference to nearby experiments. However, in order to raise the efficiency of water pumping, lining the bottom of caves with an impermeable layer is suggested.

\section{Impermeable Layer Setting}

Setting an impermeable layer in the bottom of the caves can reduce the connection between cave water and groundwater. The function of this layer can be demonstrated in two aspects. Firstly, an impermeable layer in the bottom of caves can retard groundwater recharge to cave during normal conditions and control sudden groundwater rises or declines in the caves. Secondly, when groundwater is pumped manually, it can quickly enhance the efficiency to reduce water table in the caves. Non-polluted and recycled impermeable material should be chosen. Quartz sand is suggested as the best material.

\section{Curtain Grouting}

Curtain grouting is suggested to cut off the groundwater source in Zengpiyan Cave. From the viewpoint of engineering technology, it is feasible to take this measure (Mai and Zeng, 2009; Bai, 1996). We reference a successful case in nearby Wanfu Road which had used curtain grouting in drainage of a foundation pit. groundwater inflow decreased ten times when the grouting depth reached $25 \mathrm{~m}$ and used a double row of holes in $2 \mathrm{~m}$ intervals (Wang et al., 2006). Therefore, curtain grouting can intercept groundwater flow in concentrated runoff zone effectively (Tan, 2013). But due to high risk, heavy pollution, and irreversible engineering; curtain grouting is not suggested if there are better measures (Liu et al., 2014).

\section{Environmental Management}

Zengpiyan Cave is located in the urban Guilin City. In addition, the aquifer is a highly vulnerable karst aquifer. Urban development is changing the environment of the Zengpiyan site, including groundwater-level variation and atmospheric environmental changes. Along with an engineering treatment, an integrated and long-term scheme should be set up to protect Zengpiyan Cave. The risk of groundwater pollution is a challenge for protection of the site because the official protection area is very local. However, pollutants originate from faraway areas and from many directions, which are not clear in most conditions. It is very difficult for the Administrative Department of Zengpiyan to deal with these kinds of problems. These kinds of issues need societal awareness, including scientists, local people, and government management departments.

\section{Conclusions}

Groundwater damage reduction for the Zengpiyan Cave site requires reducing the fluctuation speed of groundwater and decreasing the intervals of groundwater flooding in the cave. Because the groundwater influence on the site is of regionalscale, it is difficult to change the natural dynamics of groundwater through local-scale engineering. Moreover, site protection requires changes in the natural environment where the site is located. Eight treatment measures are proposed by this study, in which curtain grouting has the highest impact on the environment. So curtain grouting needs to be carefully planned and conducted if it is selected. Groundwater modeling is an effective tool to learn the control mechanism of groundwater dynamics, and to evaluate the engineering measure's effectiveness. However, when groundwater modeling is used for groundwater hydrological dynamics in a karst aquifer, high precision hydrogeological information is needed, especially when the study area is small and factors which affect groundwater movement are unclear. Water pumping is an important measure to control groundwater fluctuation, but experimental verification is necessary. On the other hand, pumping test in a large scale may have a high risk of causing karst collapses. With small pumping rate used in this study, groundwater decline is less than $1 \mathrm{~m}$ so analogical measures have been used to make up the deficiency of water pumping, which provide information for evaluating the engineering measures. 
The Zengpiyan site suffers from groundwater fluctuation, which seriously threatens the preservation of the cave archaeological materials. Greater knowledge of groundwater dynamics, including relationships between hydrogeology and human activities are needed to combat this problem. To analyze the mechanism of groundwater hazard to cave relics, to provide feasible measures for relic protection, to change groundwater dynamics by engineering measures, to coordinate the relationship between relic protection and groundwater movement, all of these issues are new innovative research orientation in hydrogeology and engineering geology.

\section{Acknowledgements}

Financial support was provided by State Administration of Cultural Heritage of China (Hydrogeological investigation for groundwater hazard control engineering in Zengpiyan Relic: 2011-735), Chinese National Natural Science Foundation (41102161, 41172231, 41472239), and Chinese Geological Survey project (1212011121166). We would like to thank the reviewers who read the first draft of this paper for their constructive comments.

\section{References}

Bai WY. 1996. Design on building foundation for underground construction in Guilin. Planner. 3: 58-64.

Liu XY, Zhai GL, Fang Y, Fan ZL. 2014. Impermeable grouting mechanism and parameter analysis of fracture rock in longmen grottoes. Chinese Journal of Rock Mechanics and Engineering. S2: 3941-3947.

Mai RQ, Zeng XB. 2009. Application of Curtain Grouting in Bridge Pier Construction. Exploration engineering (Rock-soil drilling and digging engineering). $8: 66-68$.

Mo BK, Zhang BQ. 2011. On causes of and countermeasures for urban waterlogging in Guilin. Guangxi Urban Construction. 8: 91-94.

Qin ZJ, Lin YS, Gao MG, Zhou H, Wei J. 2011. Causes of Karst Groundwater Damage to the Zengpiyan Ruins of Guilin and the Prevention and Control Countermeasures. Acta Geoscientica Sinica. 32 (1): $107-113$

Tan HY. 2013. Application of Grouting for Waterproof for Urban Roads in Water Rich Area. Subgrade engineering. 2: 161-164.

Wang DL, Wang T, Zhang ZJ. 2006. Reconnaissance and harnessing for water control in basic pit of shallow overburden type karst area. Mineral Resources and Geology. 06: 693-696.
Wei J. 2011. Distribution and knowledge of prehistory caves sites in Guilin Basin. In: Xi'an Banpo Museum and Guilin Zengpiyan Archaeological Sites Museum, Prehistory 2010, Guangxi Science and Technology Press, Nanning. pp 206-215. 